Check for updates

Cite this: RSC Adv., 2018, 8, 15215

Received 6th February 2018

Accepted 26th March 2018

DOI: $10.1039 / \mathrm{c} 8 \mathrm{ra01160e}$

rsc.li/rsc-advances

\section{Bismuth film electrode and chloranilic acid as a new alternative for simple, fast and sensitive Ge(Iv) quantification by adsorptive stripping voltammetry}

\author{
Malgorzata Grabarczyk (iD* and Marzena Adamczyk
}

\begin{abstract}
An analytical procedure regarding the voltammetric determination of germanium(iv) by adsorptive stripping voltammetry (AdSV) exploiting the in situ plated bismuth film electrode (BiFE) is described. The use of mercury free electrode as a working electrode is the first time proposed in AdSV germanium determination. The method is based on adsorptive accumulation of the Ge(IV)-chloranilic acid complex at a BiFE by a nonelectrochemical process followed by the cathodic stripping step. Experimental variables, including bismuth and chloranilic acid concentrations, deposition potential and time were carefully optimized. Under optimized conditions the cathodic stripping peak current was directly proportional to the concentration of Ge(Iv) in the range from $3 \times 10^{-9}$ to $1.5 \times 10^{-7} \mathrm{~mol} \mathrm{~L}^{-1}$ with the correlation coefficient 0.997. Because the AdSV technique could be invalidated due to real samples matrix the influence of foreign ions, surface active substances, and humic substances on the Ge(IV) signal was precisely examined. The satisfying minimization of potential matrix interferences was also suggested. Analytical results of natural water samples analysis showed that the proposed procedure of trace germanium(Iv) determination is suitable for direct environmental water analysis.
\end{abstract}

\section{Introduction}

Germanium has both metallic and nonmetallic properties, similarly to its counterparts in group 14 of the periodic table (carbon, silicon, tin and lead). It has a valence of +2 or +4 but it is usually quadrivalent. Germanium comes in two forms: organic and inorganic, the properties of which differ. The organic form is beneficial for human health, it is believed to have antioxidant properties and anticancer effects. Organic bound germanium is an important element for the immune system and it could capture and discharge the heavy metal toxins such as cadmium and lead. ${ }^{1-4}$ That is why organic germanium began to be used as an ingredient in health foods and dietary supplements. The germanium-containing supplements became popular in the 1980 s and the most common organic germanium compound is known as Ge-132 with the chemical name biscarboxyethyl germanium sesquioxide. However, from the very beginning there was much confusion surrounding the safety of this trace mineral. In 1989 the UK Department of Health warned against germanium supplements holding that they had no nutritional or medical value and that taking them was a health risk, rather than a benefit. ${ }^{5}$ The inorganic form of germanium is generally considered toxic, as its high intakes can lead to accumulation inside the body and create health hazards. Relatively high doses of germanium

Faculty of Chemistry, Maria Curie-Sklodowska University, 20-031 Lublin, Poland. E-mail: mgrabarc@poczta.umcs.lublin.pl; Fax: +48 81 5375553; Tel: +48815375588 dioxide $\left(\mathrm{GeO}_{2}\right)$ and other inorganic germanium compounds caused severe poisoning including impairments in kidneys, nerves, muscles, and bone marrow. ${ }^{1-4}$

Germanium and its compounds or alloys are widely used in the optical and electronics industries, which presently develop toward smaller and more powerful devices requiring small, high density semiconductor materials. The largest use of germanium is now in the production of infrared sensing and identification systems. $^{6-10}$ As a result, the world production of germanium products is now increasing and the level of germanium in the environment is beginning to rise. Moreover, germanium is often present in very low levels in environmental waters, ${ }^{11}$ so it is necessary to perform the determination of trace amounts of germanium in environmental water samples.

The adsorptive stripping voltammetry is a powerful technique for the determination of trace metals in environmental samples. The major advantages of this method are simple and cheap apparatus featuring fast response and high sensitivity, affording adsorptive accumulation of the determined metal as a complex. In the literature several complexing agents for adsorptive accumulation of germanium were employed such as pyrogallol, ${ }^{12}$ 3,4-dihydroxybenzaldehyde (DHB), ${ }^{13}$ pyrocatechol violet, ${ }^{14}$ catechol, ${ }^{15-18}$ gallic acid, ${ }^{19}$ and recently chloranilic acid. $^{20}$

A key element of AdSV procedures besides the complexing agent is the kind of working electrode on which the adsorption of metal complexes is performed. Mercury electrodes are almost ideal for this application, so they were used in the 
overwhelming majority of voltammetric procedures of metals determination. However, the toxicity of mercury electrodes is a serious drawback, so the search for suitable and less toxic electrodes began. A breakthrough in this field was the year 2000 when the bismuth film electrode was introduced by Wang's team. ${ }^{21-23}$ In the following years numerous analytical applications of this electrode were described in the literature for trace determinations of different metals, such as $\mathrm{As}(\mathrm{III}), \mathrm{Cd}(\mathrm{II}), \mathrm{Co}(\mathrm{II})$, $\mathrm{Cr}(\mathrm{VI}), \mathrm{Fe}(\mathrm{III}), \mathrm{Ga}(\mathrm{III}), \mathrm{In}(\mathrm{III}), \mathrm{Ni}(\mathrm{II}), \mathrm{Pb}(\mathrm{II}), \mathrm{Sb}(\mathrm{III}), \mathrm{Ti}(\mathrm{IV}), \mathrm{Tl}(\mathrm{I}) .^{\mathbf{2 4 - 4 2}}$

In the case of germanium, which is the subject of this work, in almost all AdSV procedures described in the literature mercury electrodes were used ${ }^{\mathbf{1 2 - 2 0}}$ and only in one paper the bismuth film electrode (BiFE) was proposed. ${ }^{21}$ This may indicate that it is very difficult to replace the toxic mercury electrode by the more environmentally friendly mercury free electrode in compliance with requested analytical parameters. We have described a new adsorptive voltammetric strategy for trace germanium determination using the bismuth film electrode as a working electrode and chloranilic acid as a complexing agent. The main advantage of this procedure of germanium determination in comparison with the earlier described procedure using bismuth film electrode ${ }^{21}$ is the method of preparation of the working electrode. Zhong et al. recommend that the bismuth film electrode should be organized in ex situ mode, which required an additional step of applying the potential of $-1.0 \mathrm{~V}$ for $5 \mathrm{~min}$ in a separate voltammetric cell and next the transfer of the three-electrode system to a new voltammetric cell containing the analyzed sample where accumulation of germanium for $150 \mathrm{~s}$ was performed. ${ }^{21}$ In our procedure the in situ bismuth film electrode was used, so the whole measurement including preparation of BiFE, germanium accumulation, and stripping was performed in one cell and proceeded in less than one minute.

Another advantage of our procedure is its insensitivity to relatively high concentrations of organic compounds, such as surface active compounds, humic compounds and natural organic matter, which disturb the voltammetric signal of germanium in other voltammetric procedures using both the bismuth film electrode ${ }^{21}$ and the mercury electrode. ${ }^{19}$

\section{Experimental}

\subsection{Apparatus}

The measurements were performed using a $\mu$ Autolab PGSTAT 10 analyzer (Utrecht, The Netherlands). The classical threeelectrode voltammetric quartz cell consisted of a glassy carbon electrode give supplier on which bismuth film was in situ plated, a Pt wire as an auxiliary electrode and an $\mathrm{Ag} / \mathrm{AgCl}$ reference electrode (saturated $\mathrm{NaCl}$ ). Before each series of measurements the glassy carbon electrode of $1 \mathrm{~mm}$ diameter was polished daily on 2000 grit sandpaper whereupon using 0.3 $\mu \mathrm{m}$ alumina slurry on the Buehler polishing pad.

\subsection{Reagents}

A stock solution of $1 \mathrm{~g} \mathrm{~L}^{-1} \mathrm{Ge}(\mathrm{Iv})$ was obtained from Merck (Darmstadt, Germany), the working solutions of Ge(Iv) of lower concentrations were prepared by dilution of the stock solution by $5 \times 10^{-3} \mathrm{~mol} \mathrm{~L}^{-1}$ of $\mathrm{HNO}_{3}$ as required. A standard solution of $1 \mathrm{~g} \mathrm{~L}^{-1} \mathrm{Bi}(\mathrm{III})$, chloranilic acid, Triton X-100, sodium dodecyl sulfate (SDS), and cetyltrimethylammonium bromide (CTAB) were purchased from Fluka (Buchs, Switzerland). A working solution of $1 \times 10^{-2} \mathrm{~mol} \mathrm{~L}^{-1}$ of chloranilic acid was prepared by dissolving $0.0209 \mathrm{~g}$ of the reagent in water in a $10 \mathrm{~mL}$ volumetric flask. Suprapur $\mathrm{CH}_{3} \mathrm{COOH}$ and $\mathrm{NaOH}$ were obtained from Merck. Humic acid sodium salt (HA) was obtained from Aldrich. Natural organic matter (NOM) and river fulvic acid (FA) were obtained from the Suwannee River and purchased from the International Humic Substances Society. Biosurfactant (rhamnolipids) and Amberlite XAD-7 resin were obtained from Sigma (St. Luis, MO, USA). Amberlite XAD-7 was washed four times with triply distilled water before use and dried at the temperature of $50{ }^{\circ} \mathrm{C}$.

\subsection{Sample preparation}

In order to minimize organic matrix interferences the samples containing surfactants or humic substances were mixed with the Amberlite XAD-7 resin before the voltammetric measurement. For this purpose a sample solution, $1 \mathrm{~mL}$ of $1 \mathrm{~mol} \mathrm{~L}^{-1}$ $\mathrm{CH}_{3} \mathrm{COOH}$ and an adequate volume of triply distilled water, so that the final volume of the solution was $10 \mathrm{~mL}$, were added to a glass vial and next $0.5 \mathrm{~g}$ of XAD-7 resin was inserted. Then, the resulting solutions was stirred using a magnetic stirring bar for 5 min. During that time the organic substances were adsorbed on the resin, while germanium(Iv) ions remained in solution. Finally, after sedimentation of the resin $5 \mathrm{~mL}$ of the solution was pipetted into the electrochemical cell, and a voltammetric measurement was performed.

\subsection{Measurement procedure}

All voltammetric measurements were carried out in $0.1 \mathrm{~mol} \mathrm{~L}^{-1}$ acetic acid solution containing $2.5 \times 10^{-5} \mathrm{~mol} \mathrm{~L}^{-1} \mathrm{Bi}(\mathrm{III})$ to generate bismuth film and $5 \times 10^{-4} \mathrm{~mol} \mathrm{~L}^{-1}$ chloranilic acid as a complexing agent. The experiments were carried out in nondeaerated solutions at room temperature. The voltammetric procedure consisted of the following main steps:

- $-1.0 \mathrm{~V}$ for $20 \mathrm{~s}$ (bismuth film was plated by the reduction of Bi(III) to bismuth metallic state);

- $-0.35 \mathrm{~V}$ for $30 \mathrm{~s}$ (accumulation of Ge(Iv)-chloranilic acid complexes on BiFE);

- the potential was scanned from $-0.35 \mathrm{~V}$ to $-0.8 \mathrm{~V}$ (differential pulse stripping voltammogram was recorded corresponding to the reduction of the accumulated complex; the germanium peak appeared at about $-0.54 \mathrm{~V}$ ).

A magnetic stirrer was used during the first two steps. After each measurement the electrochemical cleaning was carried out in the following way: $-1.4 \mathrm{~V}$ for $15 \mathrm{~s}$ and $+0.3 \mathrm{~V}$ for $15 \mathrm{~s}$ under stirring. During the first step the products from the measurement were reduced to the metallic state and then they and bismuth film were stripped from the glassy carbon electrode. 


\section{Optimization of analytical conditions}

\subsection{Supporting electrolyte}

The influence of electrolyte composition on the peak current of germanium using the in situ plated BiFE was investigated separately. The previous articles about the application of such a working electrode show that the acetic acid solution should be used. Among electrolytes that were investigated in this work, such as $\mathrm{H}_{2} \mathrm{SO}_{4}, \mathrm{HNO}_{3}, \mathrm{HClO}_{4}, \mathrm{HCl}, \mathrm{CH}_{3} \mathrm{COOH}$, the best results (higher sensitivity) were obtained in acetic acid solution. So the effect of $\mathrm{CH}_{3} \mathrm{COOH}$ concentration was studied in the range from 0.05 to $0.2 \mathrm{~mol} \mathrm{~L}^{-1}$. The experiments showed that in the whole concentration range the analytical signal of germanium was the same. Consequently, as the supporting electrolyte $0.1 \mathrm{~mol} \mathrm{~L}^{-1}$ $\mathrm{CH}_{3} \mathrm{COOH}$ was used for further measurements.

\subsection{Bismuth concentration}

In the case of an in situ plated bismuth film electrode Bi(III) should be added directly to the sample solution in the presence of acetic acid supporting electrolyte to avoid its hydrolysis. So the influence of $\mathrm{Bi}(\mathrm{III})$ concentration was studied for the synthetic solution containing $0.1 \mathrm{~mol} \mathrm{~L}^{-1} \mathrm{CH}_{3} \mathrm{COOH}, 5 \times$ $10^{-4}$ mol L ${ }^{-1}$ chloranilic acid, and $5 \times 10^{-8} \mathrm{~mol} \mathrm{~L}^{-1} \mathrm{Ge}(\mathrm{Iv})$ while the concentration of $\mathrm{Bi}(\mathrm{III})$ was changed from 0 to $1 \times$ $10^{-4} \mathrm{~mol} \mathrm{~L}^{-1}$. The obtained results are presented in Fig. 1. It was observed that the presence of the bismuth film is necessary to obtain the analytical signal for germanium. At $\mathrm{Bi}$ (III) concentration ranging from $2.5 \times 10^{-6} \mathrm{~mol} \mathrm{~L}^{-1}$ to $2.5 \times$ $10^{-5} \mathrm{~mol} \mathrm{~L}^{-1}$ the peak current of germanium increased and finally reached a maximum and next with the increase of

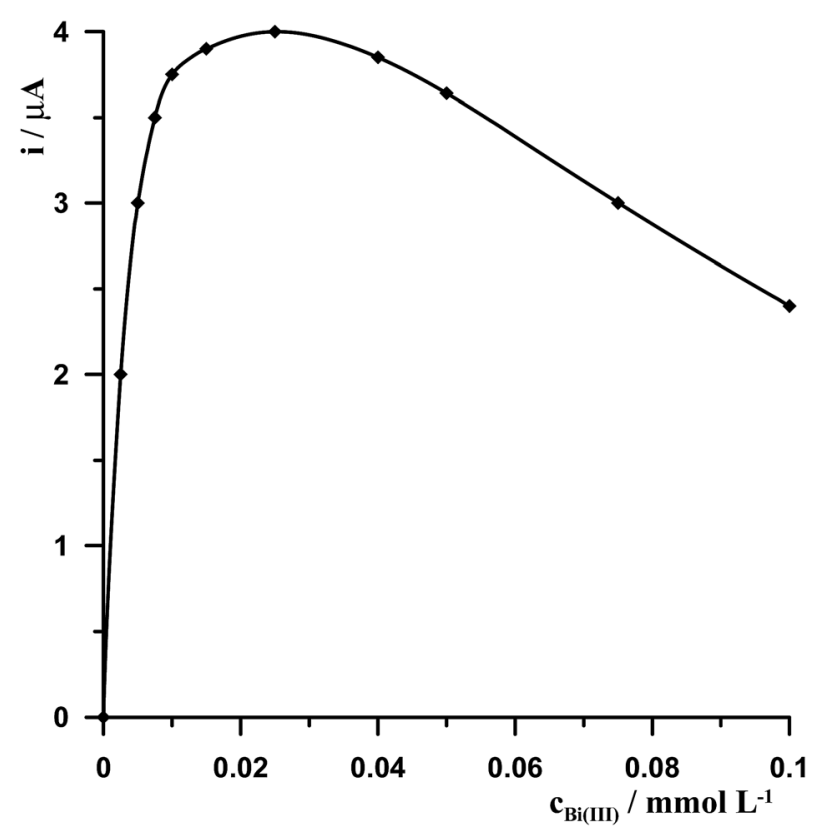

Fig. 1 The influence of $\mathrm{Bi}\left(\right.$ III) concentration on $5 \times 10^{-8} \mathrm{~mol} \mathrm{~L}^{-1} \mathrm{Ge}(\mathrm{IV})$ voltammetric signal. Concentrations of $5 \times 10^{-4} \mathrm{~mol} \mathrm{~L}^{-1}$ chloranilic acid and $0.1 \mathrm{~mol} \mathrm{~L}^{-1} \mathrm{CH}_{3} \mathrm{COOH}$. bismuth concentration the germanium signal progressively decreased. On the basis of these results the $\mathrm{Bi}(\mathrm{III})$ concentration of $2.5 \times 10^{-5} \mathrm{~mol} \mathrm{~L}^{-1}$ was chosen as the optimal one.

\subsection{Chloranilic acid concentration}

The chloranilic acid concentration had a considerable effect on the linear range and sensitivity of the method, so it was studied for $\mathrm{Ge}(\mathrm{Iv})$ at the levels of $1 \times 10^{-8} \mathrm{~mol} \mathrm{~L}^{-1}$ and $5 \times 10^{-8} \mathrm{~mol} \mathrm{~L}^{-1}$, while other standard measuring conditions remained constant (0.1 $\mathrm{mol} \mathrm{L}^{-1} \mathrm{CH}_{3} \mathrm{COOH}, 2.5 \times 10^{-5} \mathrm{~mol} \mathrm{~L}^{-1} \mathrm{Bi}(\mathrm{III})$ ). Chloranilic acid concentration was changed from 0 to $2 \times 10^{-3} \mathrm{~mol} \mathrm{~L}^{-1}$. The results show that in the absence or presence of low concentrations of chloranilic acid below $1 \times 10^{-4} \mathrm{~mol} \mathrm{~L}^{-1}$ the germanium signal is not observed. Then with the increase of complexing agent concentrations to $2 \times 10^{-3} \mathrm{~mol} \mathrm{~L}^{-1}$ the peak current increases, but at higher concentrations it increases very slightly. Moreover, at chloranilic acid concentration equal to 2 $\times 10^{-3} \mathrm{~mol} \mathrm{~L}^{-1}$ the linear range of the bismuth calibration curve is below one order of magnitude. So the concentration of the complexing agent equal to $5 \times 10^{-4} \mathrm{~mol} \mathrm{~L}^{-1}$ was selected as a compromise between sensitivity and the linear range of the calibration curve.

\subsection{Potential and time of bismuth film formation and $\mathrm{Ge}(\mathrm{Iv})$-chloranilic acid accumulation}

The effect of the electrode potential on bismuth film formation and $\mathrm{Ge}(\mathrm{Iv})$-chloranilic acid accumulation was studied for a solution containing $5 \times 10^{-8} \mathrm{~mol} \mathrm{~L}^{-1} \mathrm{Ge}(\mathrm{IV})$. On the basis of the performed measurements it was found that the best signal of germanium was obtained by applying a combination of two successive steps $-1.0 \mathrm{~V}$ for $20 \mathrm{~s}$ followed by $-0.35 \mathrm{~V}$ for $30 \mathrm{~s}$. The optimization of these parameters was carried out by changing the second potential while the first potential was fixed and then the second potential was fixed while the first potential was modified. So at first the potential $-1.0 \mathrm{~V}$ and time $20 \mathrm{~s}$ were selected for bismuth film formation while the potential of $\mathrm{Ge}(\mathrm{Iv})$-chloranilic acid accumulation was changed in the range from $-0.5 \mathrm{~V}$ to $-0.2 \mathrm{~V}$ and accumulation time $30 \mathrm{~s}$. The obtained results are presented in Fig. 2a. It was found that for the potential of accumulation in the range from $-0.4 \mathrm{~V}$ to $-0.3 \mathrm{~V}$ the peak of germanium was the same, whereas for less negative and more negative potentials the peak height decreased. Therefore, the potential of $-0.35 \mathrm{~V}$ for $\mathrm{Ge}(\mathrm{IV})$-chloranilic acid accumulation was selected as the optimum one. The effect of $\mathrm{Ge}(\mathrm{IV})$-chloranilic acid accumulation time was tested from $10 \mathrm{~s}$ to $60 \mathrm{~s}$ using the accumulation potential of $-0.35 \mathrm{~V}$. We have observed that the peak current of germanium increased as the accumulation time increased, however for a time longer than $30 \mathrm{~s}$ the growth of bismuth peak current was slight (Fig. 3a).

Then the potential of Ge(Iv)-chloranilic acid accumulation was fixed and was equal to $-0.35 \mathrm{~V}$ and $30 \mathrm{~s}$ accumulation time, while the potential of bismuth film formation was changed in the range from $-1.2 \mathrm{~V}$ to $-0.6 \mathrm{~V}$ at $20 \mathrm{~s}$. The obtained results are presented in Fig. 2b. To sum up the obtained results, in the range from $-1.1 \mathrm{~V}$ to $-0.9 \mathrm{~V}$ the peak of germanium remained the same, so the potential of $-1.0 \mathrm{~V}$ for bismuth film formation 


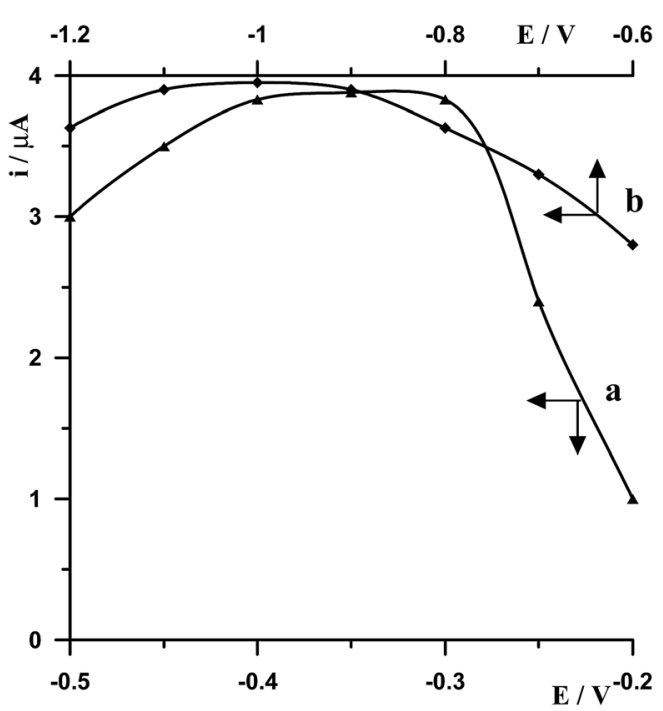

Fig. 2 The influence of potential of Ge(Iv)-chloranilic acid complex accumulation (a) and bismuth film formation (b) on $5 \times 10^{-8} \mathrm{~mol} \mathrm{~L}^{-1}$ $\mathrm{Ge}(\mathrm{Iv})$ voltammetric signal. Concentrations of $2.5 \times 10^{-5} \mathrm{~mol} \mathrm{~L}^{-1} \mathrm{Bi}(\mathrm{III})$, $5 \times 10^{-4} \mathrm{~mol} \mathrm{~L}^{-1}$ chloranilic acid, and $0.1 \mathrm{~mol} \mathrm{~L}^{-1} \mathrm{CH}_{3} \mathrm{COOH}$.

was chosen as an optimum value. The effect of bismuth film formation time was tested by changing from $10 \mathrm{~s}$ to $60 \mathrm{~s}$ using the potential of $-1.0 \mathrm{~V}$. The peak current of germanium increased as the film formation time increased to $30 \mathrm{~s}$ and next progressively decreased (Fig. 3b).

\subsection{Analytical parameters}

The calibration graph for the determination of germanium was obtained for the solution under the optimized conditions, $0.1 \mathrm{~mol} \mathrm{~L}^{-1} \mathrm{CH}_{3} \mathrm{COOH}, 2.5 \times 10^{-3} \mathrm{~mol} \mathrm{~L}^{-1} \mathrm{Bi}(\mathrm{III})$, and $5 \times$ $10^{-4} \mathrm{~mol} \mathrm{~L}^{-1}$ chloranilic acid. Under such conditions the calibration graph for $\mathrm{Ge}(\mathrm{Iv})$ was linear in the range from $3 \times 10^{-9}$ to $1.5 \times 10^{-7} \mathrm{~mol} \mathrm{~L}^{-1}$ and obeyed the equation $y=73.12 x+0.15$, where $y$ and $x$ are the peak current ( $\mu$ ampere) and Ge(Iv) the concentration ( $\mu \mathrm{mol}$ per liter), respectively. The linear correlation coefficient was $r=0.997$. The precision expressed as the relative standard deviation (R.S.D.) was 3.3\% for five successive measurements of the same sample $5 \times 10^{-9} \mathrm{~mol} \mathrm{~L}^{-1} \mathrm{Ge}(\mathrm{Iv})$. The detection limit estimated from three times the standard deviation at low Ge(Iv) concentration was about $1.2 \times 10^{-9} \mathrm{~mol} \mathrm{~L}^{-1}$.

\section{Interferences}

\subsection{Effect of foreign ions}

Interferences in the adsorptive voltammetric procedure may be caused by foreign ions as a result of their competitive adsorption or their complexes on the working electrode surface. The effects of co-existing ions were tested using a fixed concentration of $\mathrm{Ge}(\mathrm{Iv})$ equal to $1 \times 10^{-7} \mathrm{~mol} \mathrm{~L}^{-1}$ and different concentrations of several foreign ions. An ion was considered to interfere when its presence produced a variation in the germanium peak current $>5 \%$. The results showed that up to a 100 fold excess of $\mathrm{Al}(\mathrm{III}), \mathrm{Ca}(\mathrm{II}), \mathrm{Cr}(\mathrm{III}), \mathrm{Cr}$ (VI), $\mathrm{Cu}$ (II), $\mathrm{Ga}$ (III), In(III),

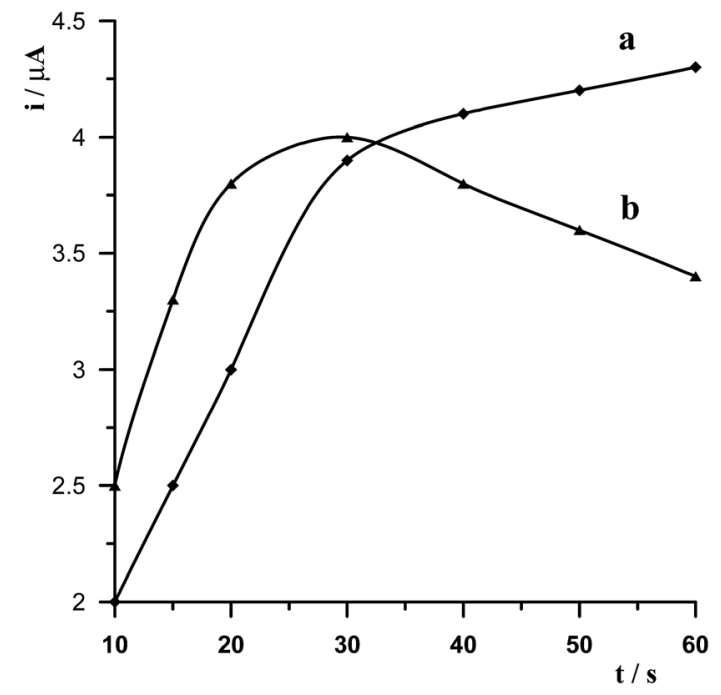

Fig. 3 The influence of Ge(Iv)-chloranilic acid complex accumulation (a) and time of bismuth film formation (b) on $5 \times 10^{-8} \mathrm{~mol} \mathrm{~L}^{-1} \mathrm{Ge}(\mathrm{IV})$ voltammetric signal. Concentrations of $2.5 \times 10^{-5} \mathrm{~mol} \mathrm{~L}^{-1} \mathrm{Bi}(\mathrm{III}), 5 \times$ $10^{-4} \mathrm{~mol} \mathrm{~L}^{-1}$ chloranilic acid, and $0.1 \mathrm{~mol} \mathrm{~L}^{-1} \mathrm{CH}_{3} \mathrm{COOH}$.

$\mathrm{Mg}$ (II), Mn(II), Pb(II), V(v), Zn(II), and 50-fold excess of $\mathrm{Co}(\mathrm{II})$, $\mathrm{Cd}(\mathrm{II}), \mathrm{Ni}$ (II), $\mathrm{Fe}(\mathrm{III}), \mathrm{Sb}$ (III) did not have a significant effect on the $\mathrm{Ge}(\mathrm{Iv})$ peak. The most interfering ions were $\mathrm{Hg}$ (II), $\mathrm{Mo}(\mathrm{VI}), \mathrm{Se}(\mathrm{IV})$, and Ti(Iv) whose 50-fold excess caused a decrease of the germanium peak to $40 \%, 70 \%, 75 \%$, and $40 \%$ of its original value, respectively. The voltammograms recorded for solutions containing $1 \times 10^{-7} \mathrm{~mol} \mathrm{~L}^{-1} \mathrm{Ge}(\mathrm{IV})$ and $5 \times 10^{-6} \mathrm{~mol} \mathrm{~L}^{-1}$ interfering ions: $\mathrm{Hg}(\mathrm{II}), \mathrm{Mo}(\mathrm{VI}), \mathrm{Se}(\mathrm{Iv})$ and $\mathrm{Ti}(\mathrm{IV})$ are presented in Fig. 4.

\subsection{Effect of surface active and humic substances}

One of the drawbacks of adsorptive voltammetric methods is the sensitivity to organic matter, such as surface active and humic substances which are present in real samples. The interferences are caused mainly by the adsorption of those substances on the working electrode and consequently its blockade, which in turn results in a decrease or total decay of the analytical signal of the determined element. Organic matter

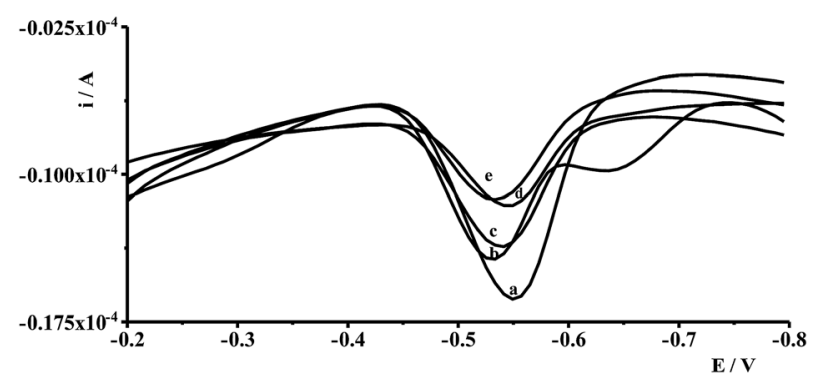

Fig. 4 The voltammograms recorded for solutios containing: $2 \times$ $10^{-8} \mathrm{~mol} \mathrm{~L}^{-1} \mathrm{Ge}(\mathrm{IV})(\mathrm{a}), 2 \times 10^{-8} \mathrm{~mol} \mathrm{~L}^{-1} \mathrm{Ge}(\mathrm{Iv})$ and $1 \times 10^{-6} \mathrm{~mol} \mathrm{~L}^{-1}$ $\mathrm{Se}(\mathrm{Iv})$ (b), $2 \times 10^{-8} \mathrm{~mol} \mathrm{~L}^{-1} \mathrm{Ge}(\mathrm{Iv})$ and $1 \times 10^{-6} \mathrm{~mol} \mathrm{~L}^{-1} \mathrm{Mo}(\mathrm{vl})$ (c) $2 \times$ $10^{-8} \mathrm{~mol} \mathrm{~L}{ }^{-1} \mathrm{Ge}(\mathrm{IV})$ and $1 \times 10^{-6} \mathrm{~mol} \mathrm{~L}{ }^{-1} \mathrm{Hg}(\mathrm{II})(\mathrm{d}), 2 \times 10^{-8} \mathrm{~mol} \mathrm{~L}^{-1}$ $\mathrm{Ge}(\mathrm{Iv})$ and $1 \times 10^{-6} \mathrm{~mol} \mathrm{~L}^{-1} \mathrm{Ti}(\mathrm{Iv})(\mathrm{e})$. 
Table 1 The influence of different organic substances on $5 \times 10^{-8} \mathrm{~mol} \mathrm{~L}{ }^{-1} \mathrm{Ge}(\mathrm{IV})$ analytical signal using the standard procedure and the procedure with mixing with Amberlite XAD-7 resin

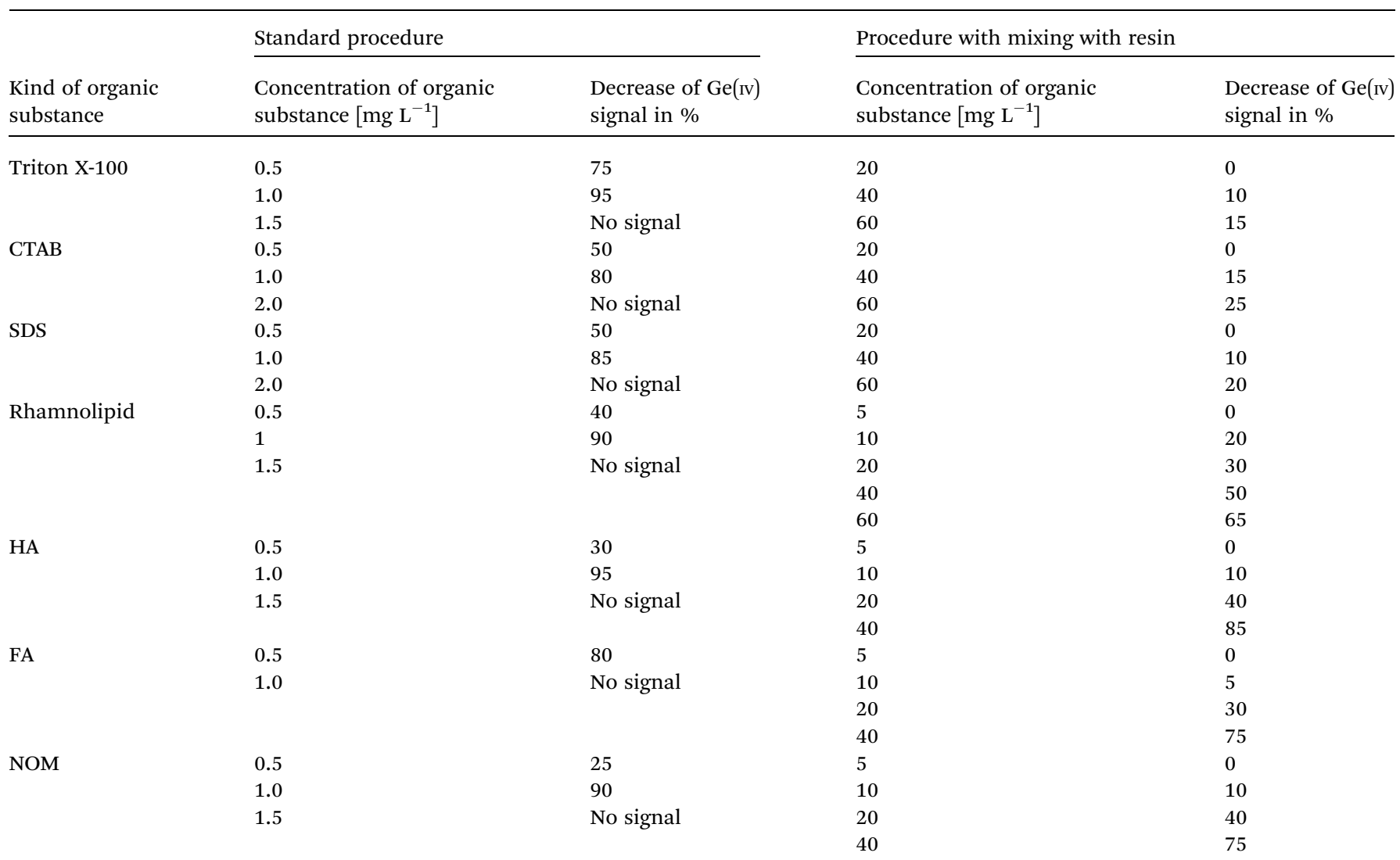

interferences also concern adsorptive voltammetric determination of germanium using as a working electrode the mercury electrodes ${ }^{19,20}$ as well as BiFE as we have proved in this work. The measurements were performed by testing the influence of different kinds of surfactants on the germanium signal, such as Triton X-100 (non-ionic), cetyltrimethylammonium bromide (CTAB-cationic), sodium dodecylsulfate (SDS-anionic), and rhamnolipid (biosurfactant), humic acids (HA), fulvic acids (FA), and natural organic matrix (NOM). The experiments were performed by measuring the peak height of the germanium signal using the solutions containing a constant concentration of Ge(rv) equal to $5 \times 10^{-8} \mathrm{~mol} \mathrm{~L}^{-1}$ and different concentrations

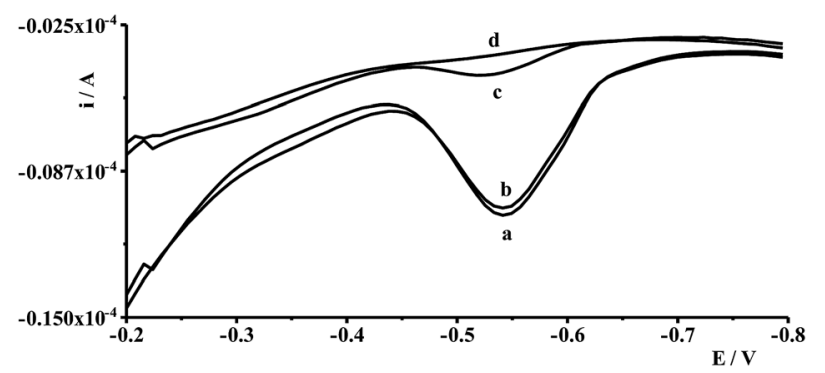

Fig. 5 The voltammograms illustrating the influence of Triton X-100 on the $5 \times 10^{-8} \mathrm{~mol} \mathrm{~L}^{-1} \mathrm{Ge}(\mathrm{Iv})$ : (a) no Triton $\mathrm{X}-100$ without resin; (b) $20 \mathrm{mg} \mathrm{L}^{-1}$ Triton X-100 with resin; (c) $0.5 \mathrm{mg} \mathrm{L}^{-1}$ Triton X-100 without resin; and (d) $1.5 \mathrm{mg} \mathrm{L}^{-1}$ Triton $\mathrm{X}-100$ without resin. of the organic substances. It was concluded that the voltammetric signal of germanium is very sensitive to the presence of both surface active substances and humic substances and that their concentrations in the range of $1-2 \mathrm{mg} \mathrm{L}^{-1}$ cause total decay of the germanium peak current. So with a view to eliminate these interferences the preliminary mixing of the analyzed sample with Amberlite XAD-7 resin as described in chapter Sample preparation was introduced. During this step the organic substances have a tendency to adsorb on the resin while the monitored germanium ions remain in solution. Applying such a procedure the organic substances do not affect the germanium signal in the concentration range of $5-20 \mathrm{mg} \mathrm{L}^{-1}$. Detailed results of the influence of different kinds of surface active substances and humic substances using a standard procedure and the procedure with mixing with the resin are presented in Table 1. In Fig. 5 the examples of voltammograms recorded in the presence of different concentrations of Triton X1000 using the procedure with or without mixing with resin are shown.

\section{Application of the proposed procedures}

In order to validate the proposed procedure, recovery tests were carried out by taking four fresh natural water samples collected from different places and by adding known quantities of Ge(rv) 


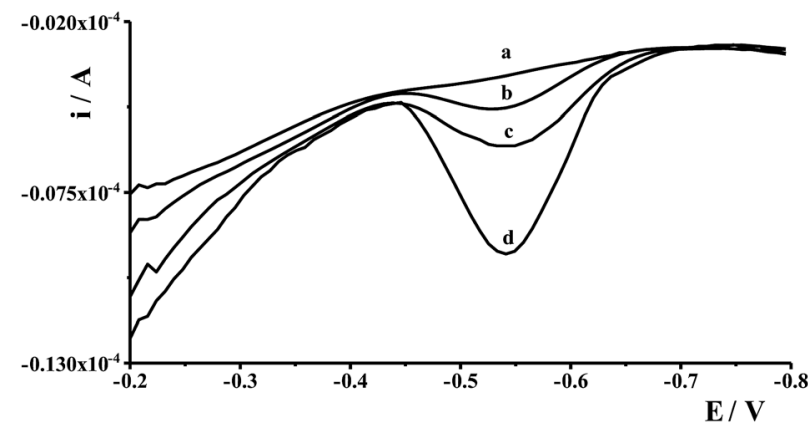

Fig. 6 Differential pulse voltammograms obtained during Ge(Iv) determination in Lake Zemborzyce stagnant water: diluted five-fold (a); as (a) $+1 \times 10^{-8} \mathrm{~mol} \mathrm{~L}^{-1} \mathrm{Ge}(\mathrm{Iv})$ (b); as (a) $+2 \times 10^{-8} \mathrm{~mol} \mathrm{~L}^{-1} \mathrm{Ge}(\mathrm{Iv})$ (c); as (a) $+5 \times 10^{-8} \mathrm{~mol} \mathrm{~L}^{-1} \mathrm{Ge}(\mathrm{Iv})$ (d).

standard in the sample. The samples were collected from eastern areas of Poland, river waters (the Bystrzyca and the Krezniczanka rivers), stagnant water (Lake Zemborzyce), tap water and were submitted to analysis without any pretreatment. The voltammograms obtained in the course of Ge(Iv) determination for water samples did not exhibit any signals, so the analyzed samples were spiked with $\mathrm{Ge}(\mathrm{Iv})$ at different concentration levels and analyzed using the standard addition method based on three runs of measurements. The results of the recovered values were found to be within $\pm 4.7 \%$, which proved that the proposed procedure was adequately satisfactory for the analysis of natural water samples. The voltammograms obtained during the analysis of Lake Zemborzyce stagnant water are presented in Fig. 6.

\section{Conclusions}

The bismuth film electrode and chloranilic acid as a new alternative for the simple, fast and sensitive Ge(Iv) quantification by adsorptive stripping voltammetry were successfully proposed. The main advantage of the procedure is that the toxic mercury electrode was replaced by a more environmentally friendly in situ plated bismuth film electrode as a working electrode. The application of an in situ formed film electrode shortens the total time of measurements. Another advantage is the possibility to carry out the measurements in undeaerated solutions. Moreover, the proposed adsorptive stripping voltammetric method offers the advantages of accuracy as well as simplicity of reagents and apparatus. It should also be mentioned that the described procedure is insensitive to high concentrations of surface active substances and humic substances. To prove its practical applicability, the procedure was successfully tested for the detection of germanium in different non-pretreated and non-deaerated real water samples.

\section{Conflicts of interest}

There are no conflicts to declare.

\section{References}

1 L. S. Keith, O. M. Faroon, N. Maples-Reynolds and B. E. Fowler, Germanium, Handbook on the Toxicology of Metals, ed. Gunnar Nordberg, B. Fowler and M. Nordberg, Elsevier, 4th edn, 2014, pp. 799-816.

2 M. Banasik, Germanium, in Hamilton and Hardy's Industrial Toxicology, ed. Raymond D. Harbison, M. M. Bourgeois and G. T. Johnson, Wiley, 6th edn, 2015, pp. 119-122.

3 Y. Katsuhiko, Germanium, Toxicity, in Encyclopedia of Metalloproteins, ed. R. H. Kretsinger, V. N. Uversky and E. A. Permyakov, Springer, 2013. pp. 842-846.

4 A. F. Koca, I. Koca and B. Tekguler, Acta Hortic., 2016, 1143, 297-302.

5 J. Emsley, Nature's Building Blocks: An A-Z Guide to the Elements, Oxford University Press, New York, 2011, pp. 197-201.

6 E. Rosenberg, Rev. Environ. Sci. Bio/Technol., 2009, 8, 29-57.

7 R. R. Moskalyk, Miner. Eng., 2004, 17, 393-402.

8 B. Depuydt, A. Theuwis and I. Romandi, Mater. Sci. Semicond. Process., 2006, 9, 437-443.

9 E. E. Haller, Mater. Sci. Semicond. Process., 2006, 9, 408-422. 10 N. S. Medvedev, A. V. Shaverina, A. R. Tsygankova and A. I. Saprykin, Talanta, 2016, 155, 358-362.

11 S. Jianbo, T. Zhiyong, T. Chunhua, Ch. Quan and J. Zexiang, Talanta, 2002, 56, 711-716.

12 Ch. Q. Sun, Q. Gao and L. L. Liu, Talanta, 1995, 42, 881-884.

13 Ch. Q. Sun, Q. Gao, J. Xi and H. Xu, Anal. Chim. Acta, 1995, 309, 89-93.

14 A. M. Bond, S. Kratsis and O. M. G. Newman, Electroanalysis, 1998, 10, 387-392.

15 J. L. Muniz Alvarez, J. A. Garcia Calzon and J. M. Lopez Fonseca, Electroanalysis, 1999, 11, 656-659.

16 J. L. Muniz Alvarez, J. A. Garcia Calzon and J. M. Lopez Fonseca, Talanta, 2001, 53, 721-731.

17 S. Y. Ly, S. S. Song, S. K. Kim, Y. S. Jung and Ch. H. Lee, Food Chem., 2006, 95, 337-343.

18 R. Piech, J. Appl. Electrochem., 2011, 41, 207-214.

19 Y. H. Li, X. H. Chen, M. H. Huang and F. Q. Zhou, Electroanalysis, 2007, 19, 704-708.

20 M. Grabarczyk, J. Electrochem. Soc., 2017, 164, H872-H876.

21 S. Zhong, J. Su, L. Chen, J. Tong, W. Jia, X. Li and H. Zou, Int.

J. Electrochem. Sci., 2013, 2013, 735019, 7 pages.

22 J. Wang, J. Lu, S. B. Hocevar and P. A. M. Farias, Anal. Chem., 2000, 72, 3218-3222.

23 J. Wang, J. Lu, U. A. Kirgoz, S. B. Hocevar and B. Ogorevc, Anal. Chim. Acta, 2001, 434, 29-34.

24 L. Jiajie and Y. Nagaosa, Anal. Chim. Acta, 2007, 593, 1-6.

25 A. Królicka, R. Pauliukaite, I. Svancara, R. Metelka, A. Bobrowski, E. Norkus, K. Kalcher and K. Vytras, Electrochem. Commun., 2002, 4, 193-196.

26 N. Lezi, A. Economou, P. A. Dimovasilis, P. N. Trikalitis and M. I. Prodromidis, Anal. Chim. Acta, 2012, 728, 1-8.

27 A. Krolicka, A. Bobrowski, K. Kalcher, J. Mocak, I. Svancara and K. Vytras, Electroanalysis, 2003, 15, 1859-1863. 
28 A. Królicka and A. Bobrowski, Electrochem. Commun., 2004, 6, 99-104.

29 M. Morfobos, A. Economou and A. Voulgaropoulos, Anal. Chim. Acta, 2004, 519, 57-64.

30 S. B. Hocevar, J. Wang and R. P. Deo, Electroanalysis, 2002, 14, 112-115.

31 E. Chatzitheodorou, A. Economou and A. Voulgaropoulos, Electroanalysis, 2004, 16, 1745-1754.

32 L. Lin, N. S. Lawrence, S. Thongngamdee, J. Wang and Y. Lin, Talanta, 2005, 65, 144-148.

33 M. Grabarczyk and J. Wasąg, Talanta, 2015, 144, 1091-1095.

34 J. Wasąg and M. Grabarczyk, Anal. Methods, 2016, 8, 36053612.

35 K. Wegiel, M. Grabarczyk, W. W. Kubiak and B. Baś, Electrode, J. Electrochem. Soc., 2017, 164, H352-H357.
36 G. Kefala, A. Economou and A. Voulgaropoulos, Talanta, 2003, 61, 603-610.

37 J. Su, S. Zhong, H. Li and H. Zou, J. Electrochem. Soc., 2014, 161, H512-H516.

38 A. Bobrowski, A. Królicka, K. Pacan and J. Zarębski, Electroanalysis, 2009, 21, 2415-2419.

39 K. Węgiel, J. Robak and B. Baś, RSC Adv., 2017, 7, 2202722033.

40 K. Wegiel, K. Jedlińska and B. Baś, J. Hazard. Mater., 2016, 310, 199-206.

41 B. Baś, K. Węgiel and K. Jedlińska, Electrochim. Acta, 2015, 178, 665-672.

42 B. Baś, K. Węgiel and K. Jedlińska, Anal. Chim. Acta, 2015, 881, 44-53. 